\title{
IDENTIFIKASI ACCESSIBILITY PADA OBJEK WISATA DI DESA SAMBANGAN SEBAGAI DESA WISATA
}

\author{
Putu Dewinta Arystiana ${ }^{1}$, Cokorda Istri Raka Marsiti², Ni Made Suriani ${ }^{3}$ \\ Program Studi Pendidikan Kesejahteraan Keluarga, Fakultas Teknik dan Kejuruan \\ Universitas Pendidikan Ganesha \\ Singaraja, Indonesia \\ e-mail : dewintaarystiana98@gmail.com, raka.marsiti@undiksha.ac.id, \\ made.suriani@undiksha.ac.id
}

\begin{abstract}
Abstrak
Penelitian ini bertujuan untuk (1) mendeskripsikan accessibility pada objek wisata di desa sambangan, (2) mendeskripsikan kendala dalam penyediaan accessibility pada objek wisata di desa sambangan. Jenis penelitian yang digunakan yaitu deskriptif kualitatif. Pengumpulan data dilakukan melalui metode observasi, metode wawancara dan metode dokumentasi. Instrumen yang digunakan dalam penelitian ini yaitu pedoman wawancara dan lembar observasi. Adapun hasil dari penelitian ini, antara lain: (1) accessibility pada objek wisata di desa sambangan dibagi menjadi dua yakni, pada objek wisata alam dan pada objek wisata buatan. Akses jalan pada objek wisata alam dapat diakses dengan berjalan kaki menelusuri jalan semi permanen agar lebih mudah dilalui yang berada di tengah hutan Desa Sambangan. Sedangkan akses jalan pada objek wisata buatan dapat diakses dengan menggunakan kendaraan roda dua maupun roda empat dengan kondisi jalan beraspal. Untuk akses informasi pihak pengelola objek wisata bersama dengan Kelompok Darwis Tunjung Mekar Desa Sambangan melakukan beberapa upaya dalam melakukan promosi dan publikasi antara lain : pembuatan pamflet, pemasangan baliho, dan dibagikan lewat media sosial facebook, instragram, dan website. Pada setiap objek wisata sudah disediakan area parkir untuk para wisatawan yang cukup digunakan menampung kendaraan para wisatawan. (2) kendala dalam penyediaan accessibility pada objek wisata di Desa Sambangan antara lain : letak geografis lebih ke pegunungan, pemodalan dalam menyediakan aksesibilitas tidak dapat direalisasikan untuk seluruh objek wisata, jalan menuju objek wisata terbilang sempit, kurangnya lampu penerangan jalan pada malam hari, dan pelepasan lahan.
\end{abstract}

Kata Kunci : accessibility, objek wisata, Desa Sambangan

\begin{abstract}
This study aims to (1) describe accessibility in tourist attractions in sambangan village, (2) describe the constraints in providing accessibility to tourist attractions in sambangan village. The type of research used is descriptive qualitative. Data collection is done through observation method, interview method and documentation. The instruments used in this study are interview guidelines and observation sheets. The results of this study, among others: (1) accessibility on tourist attractions in the village sambangan divided into two, namely, on natural attractions and on artificial attractions. Road access to natural attractions can be accessed by walking along a semi-permanent road to make it easier to walk in the middle of the forest of Sambangan Village. While road access at artificial attractions can be accessed by using two-wheeled or four-wheeled vehicles with paved road conditions. For access to information, the management of tourist attractions together with the Group Darwis Tunjung Mekar Sambangan Village made several efforts in conducting promotions and publications, among others: making pamphlets, installing billboards, and shared through social media facebook, instragram, and website. In each tourist attraction has been provided a parking area for tourists that is sufficiently used to accommodate the vehicles of tourists. (2) constraints in the provision of accessibility to tourist attractions in Sambangan Village include: geographical location more to the mountains, desecration in providing accessibility can not be realized for all tourist attractions, the road to tourist attractions is fairly narrow, lack of street lighting at night, and land release.
\end{abstract}

Key Word : accessibility, tourist attractions, Sambangan village 


\section{PENDAHULUAN}

Di Negara maju berwisata Bali adalah salah satu provinsi di Indonesia. Bali terletak diantara Pulau Jawa dan Pulau Lombok. Ibu Kota dari Bali adalah Denpasar yang terletak diantara bagian selatan pulau ini. Bali terdiri dari 9 kabupaten yakni, Kabupaten Badung, Kabupaten Bangli, Kabupaten Buleleng, Kabupaten Gianyar, Kabupaten Jembrana, Kabupaten Karangasem, Kabupaten Klungkung, dan Kabupaten Tabanan. Bali merupakan ikon pariwisata di Indonesia juga menjadi salah satu destinasi tujuan wisata dunia. Bali juga dikenal sebagai Pulau Dewata dan Pulau Seribu Pura. Dengan beraneka ragam keindahan sumber daya alam, seni, budaya serta kekhasan dan keunikan tradisi masyarakat Bali, sehingga hal tersebut mampu memberikan daya tarik tersendiri terhadap wisatawan baik wisatawan domestik maupun wisatawan mancanegara.

Kabupaten Buleleng merupakan salah satu kabupaten yang ada di Bali, yang letaknya di belahan utara pulau Bali. Memiliki luas wilayah 1.365,88 Km2 atau $24,25 \%$ dari luas provinsi Bali. Kabupaten Buleleng memiliki 9 Kecamatan, antara lain Kecamatan Grokgak, Kecamatan Seririt, Kecamatan Busungbiu, Kecamatan Banjar, Kecamatan Buleleng, Kecamatan Sukasada, Kecamatan Sawan, Kecamatan Kubutambahan, dan Kecamatan Tejakula. Perkembangan kunjungan wisatawan di Kabupaten Buleleng mengalami peningkatan sejak diterbitkannya Surat Keputusan Bupati tentang penetapan desa wisata di Kabupaten Buleleng Tahun 2015.

Menurut Pariwisata Inti Rakyat (PIR) Desa Wisata merupakan suatu kawasan pedesaan yang menawarkan suasana yang mencerminkan keaslian pedesaan baik dari kehidupan soial ekonomi, sosial budaya, adat istiadat, keseharian, memiliki aristektur bangunan dan struktur tata ruang desa yang khas, atau aktivitas perekonomian yang unik dan menarik serta mempunyai potensi untuk bisa dikembangkannya berbagai komponen kepariwisataan, misalnya: atraksi, akomodasi, makanan-minuman dan kebutuhan wisata lainnya. Menurut Wiendu (2015), Desa Wisata merupakan suatu bentuk integrasi antara atraksi, akomodasi dan fasilitas pendukung yang disajikan dalam suatu struktur kehidupan masyarakat yang menyatu dengan tata cara dan tradisi yang berlaku. Desa wisata biasanya memiliki kecenderungan kawasan pedesaan yang memiliki kekhasan dan daya tarik sebagai tujuan wisata.

Menurut Priasukmana \& Mulyadin (2001), Desa Wisata merupakan suatu kawasan pedesaan yang menawarkan keseluruhan suasana yang mencerminkan keaslian pedesaaan baik dari kehidupan sosial ekonomi, sosial budaya, adat istiadat, keseharian, memiliki arsitektur bangunan dan struktur tata ruang desa yang khas, atau kegiatan perekonomian yang unik dan menarik serta mempunyai potensi untuk dikembangkanya berbagai komponen kepariwisataan, misalnya atraksi, akomodasi, makanan-minuman, cindera-mata, dan kebutuhan wisata lainnya. Sebagai desa wisata, harus memenuhi beberapa persyaratan, yaitu mempunyai potensi untuk dikembangkanya berbagai komponen kepariwisataan, misalnya atraksi wisata, tersedia akomodasi yang memadai, keamanan desa yang terjamin, beriklim sejuk, adanya keterlibatan dengan masyarakat desa, serta memiliki aksesibilitas yang baik. Suasana yang mencerminkan keaslian pedesaaan baik dari kehidupan sosial ekonomi, sosial budaya, adat istiadat, keseharian, memiliki arsitektur bangunan dan struktur tata ruang desa yang khas, atau kegiatan perekonomian yang unik dan menarik serta mempunyai potensi untuk dikembangkanya berbagai komponen kepariwisataan.

Berdasarkan Surat keputusan Bupati Buleleng No. 430/927/HK/2015, Desa Sambangan ditetapkan sebagai salah satu desa wisata di Kabupaten Buleleng. Desa Sambangan merupakan salah satu desa yang terletak di Kecamatan Sukasada, Buleleng, dengan luas wilayah: $7,67 \mathrm{~km}$ atau 767,00 ha yang terbagi ke dalam 3 (tiga) banjar dinas yaitu, 
Banjar Dinas Babakan, Banjar Dinas Sambangan, dan Banjar dinas Banjar Anyar. Desa ini memiliki bentang alam yang berdekatan dengan pegunungan yang indah. Daya tarik wisata alam yang bervariasi membuat Desa Sambangan diminati oleh para wisatawan. Terdapat beberapa pesona objek wisata yang tak kalah indahnya dengan kawasan wisata lainnya, seperti Terasering Sawah Cengana, Air Terjun Cemara, Air Terjun Dedari, Air Terjun Canging, Air Terjun Aling-aling, Air Terjun Kroya, Air Terjun Kembar, Air Terjun Pucuk, dan Kolam Renang. Selain wisata alam terdapat pula wisata adventure, seperti trekking, jumping, sliding dan Camping yang dapat dilakukan oleh wisatawan di Desa Wisata Sambangan.

Dalam meningkatkan mutu pada desa wisata di Desa Sambangan tentu harus didukung oleh komponen-komponen pariwisata. Mengacu dengan komponen pariwisata 4A (Attraction, Aminities, Accessbility dan Ancillary) Desa Sambangan sudah mengelola keempat komponen tersebut dengan cukup baik dalam pengembangan Desa Wisata. Dapat dilihat dari adanya (a) atraksi pada daya tarik wisata alam, (b) atraksi wisata minat khusus, (c) tersedia akomodasi seperti villa ataupun homestay, (d) keterlibatan masyarakat dalam pelayanan pada objek wisata, serta (e) aksesibilitas yang sudah cukup memadai, karena wisatawan yang berkunjung ke desa sudah dapat diakses oleh kendaraan roda dua maupun roda empat.

Dalam komponen pariwisata 4A (Attraction, Aminities, Accessbility dan Ancillary), accessibility merupakan komponen yang penting dalam mencapai suatu objek wisata. Berdasarkan observasi awal peneliti, Desa Sambangan memiliki aksesibilitas yang cukup memadai dapat dilihat dari kondisi jalan yang beraspal dapat dilalui oleh kendaraan roda dua maupun roda empat, jarak tempuh dari pusat kota berdekatan dengan Desa Sambangan sehingga dikatakan aksesibilitas pada Desa Wisata Sambangan terbilang tinggi. Tofografi dan geografis memberikan kesan refresh kepada tamu karena dimanjakan dengan pemandangan alam sekitar Desa Sambangan. Serta adanya upaya-upaya untuk kelancaran akses yang dilakukan oleh POKDARWIS dan bekerja sama dengan masyarakat yaitu, (a) membantu memelihara lingkungan Desa Sambangan dengan cara pembersihan, gotong-royong, perbaikan pada kerusakan yang ada, (b) Membangun beberapat sign (rambu jalan) dimana letak objek, papan informasi dan papan reklame untuk memperlancar akses, (c) Melakukan take in lokasi guna mempermudah menemukan lokasi Desa Sambangan dan objek wisata di Desa Sambangan.

Aksesibilitas menurut Bambang Susantono (2004:24) merupakan suatu ukuran potensial atau kemudahan orang untuk mencapai tujuan dalam suatu perjalanan. Karekteristik sistem transportasi ditentukan oleh aksesibilitas. Aksesibilitas memberikan pengaruh pada beberapa lokasi kegiatan atau tata guna lahan. Lokasi kegiatan juga memberikan pengaruh pada pola perjalanan untuk melakukan kegiatan sehari-hari. Pola perjalanan ini kemudian mempengaruhi jaringan transportasi dan akan pula memberikan pengaruh pada sistem transportasi secara keseluruhan.

Berdasarkan latar belakang di atas maka perlu diadakan suatu penelitian yang meneliti accessibility pada objek wisata di Desa Sambangan, serta kendala apa saja yang dialami dalam menyediakan accessibility pada objek wisata di Desa Sambangan agar kegiatan pariwisata di Desa Sambangan dapat berjalan dengan lancar.

Penelitian yang telah dilakukan oleh Ketut Dewi Martha Erli $\mathrm{H}$. yang berjudul "Penentuan Prioritas Pengembangan Infrastruktur Kawasan Wisata Bahari di Desa Sumberejo, Desa Lojejer dan Desa Puger Kulon, Kabupaten Jember berdasarkan Preferensi Pengunjung dan Masyarakat" menjelaskan bahwa peran infrastruktur tidak hanya berpengaruh pada pengembangan wilayah 
saja, tetapi juga pada bidang kepariwisataan. Infrastruktur berperan sangat penting dalam mendorong kualitas wisata itu sendiri, serta pada lingkungan sekitarnya. Selain itu juga infrastruktur yang ada belum dapat mengintegrasikan kawasan wisata dikarenakan pihak pengelola dari masing-masing pantai yang berbeda, serta adanya keterbatasan dana dari pemerintah daerah.

Penelitian yang dilakukan oleh I Gusti Nyoman Taurus Cahayadi menjelaskan bahwa potensi wisata di Desa Sudaji yang dapat dikembangkan menjadi ekowisata adalah potensi alam, manusia, dan budaya. Kajian potensi ekowisata berdasarkan analisi SWOT yaitu: a). Kekuatan yang cukup besar, berupa potensi alam, potensi manusia, dan kebudayaan yang beranekaragam. b). Kelemahan potensi wisata Desa Sudaji yaitu potensi alam: beberapa sarana belum mendukung, karakteristik alam di Desa Sudaji pada musim hujan. Potensi manusia: sumber tenaga kerja sebagai local guide, keterampilan masyarakat lokal seadanya. Potensi budaya: belum optimalnya kemampuan pengelolaan atraksi seni dan budaya, belum efektifnya networking diantara para pengelola atraksi seni dan budaya daerah. C). Peluang potensi wisata Desa Sudaji. Potensi alam: adanya perubahan trend pariwisata, wisatawan lebih menikmati dan menghargai panorama alam pedesaan. Potensi manusia: meningkatkan kapasitas bagi pengelola dan pemandu wisata, meningkatkan hubungan kerjasama dengan pelaku wisata. Potensi budaya: Desa Sudaji beberapa kali ditunjuk dalam Pesta Kesenian Bali, kecendrungan wisatawan Eropa terhadap pariwisata budaya. d) Ancaman yang dapat merusak potensi ekowisata di Desa Sudaji. Potensi alam: sampah, penebangan pohon, penggunaan air. Potensi manusia: sulitnya lapangan pekerjaan, semakin berkurangnya nilai budaya setiap individu. Potensi budaya: masuknya budaya modern, dan akulturasi budaya.

Penelitian yang dilakukan oleh Novi Maryaningsih berjudul "Pengaruh Infrastruktur terhadap Pertumbuhan
Ekonomi Indonesia" menjelaskan bahwa Upaya pembenahan kondisi infrastruktur disadari peran penting dalam mengurangi kesenjangan pendapatan dan dampak jangka panjangnya bagi PDB per kapita. 5 perbaikan infrastruktur memiliki kontribusi dalam meningkatkan produktivitas dan diharapkan mampu mendukung pertumbuhan ekonomi dalam jangka panjang. Merujuk pada publikasi World Development Report (World Bank, 1994), infrastruktur berperan penting dalam meningkatkan pertumbuhan ekonomi di mana pertumbuhan ekonomi yang lebih tinggi dijumpai pada wilayah dengan tingkat ketersediaan infrastruktur yang mencukupi.

Menurut Kamus Besar Bahasa Indonesia, wisata merupakan kata kerja yang berarti: (a) bepergian bersama-sama, (b) piknik. Pari berarti: segala, semua, maka Pariwisata dapat diartikan sebagai segala sesuatu yang berhubungan dengan bepergian bersama-sama. Wisatawan berarti orang yang melakukan kegiatan wisata, atau orang yang bepergian. Objek wisata menyangkut tempat, lokasi, atau segala sesuatu yang menjadi daya Tarik untuk dikunjungi, dipelajari atau dilihat oleh wisatawan.

Menurut Priasukmana \& Mulyadin (2001), desa wisata merupakan suatu kawasan pedesaan yang menawarkan keseluruhan suasana yang mencerminkan keaslian pedesaaan baik dari kehidupan sosial ekonomi, sosial budaya, adat istiadat, keseharian, memiliki arsitektur bangunan dan struktur tata ruang desa yang khas, atau kegiatan perekonomian yang unik dan menarik serta mempunyai potensi untuk dikembangkanya berbagai komponen kepariwisataan, misalnya atraksi, akomodasi, makanan-minuman, cindera-mata, dan kebutuhan wisata lainnya.

Desa wisata biasanya berupa kawasan pedesaan yang memiliki beberapa karakteristik khusus yang layak untuk menjadi daerah tujuan wisata. Dikawasan ini, penduduknya masih memiliki tradisi dan budaya yang relative masih asli. Selain itu, beberapa faktor pendukung seperti makanan khas, sistem 
pertanian dan sistem sosial turut mewarnai sebuah kawasan desa wisata. Di luar faktor-faktor tersebut, sumberdaya alam dan lingkungan alam yang masih terjaga merupakan salah satu faktor penting dari sebuah kawasan desa wisata. Selain berbagai keunikan tersebut, kawasan desa wisata juga dipersyaratkan memiliki berbagai fasilitas untuk menunjangnya sebagai kawasan tujuan wisata. Berbagai fasilitas ini akan memudahkan para pengunjung desa wisata dalam melakukan kegiatan wisata. Fasilitas-fasilitas yang seyogyanya ada disuatu kawasan desa wisata antara lain : sarana transportasi, telekomunikasi, kesehatan, dan akomodasi. Khusus untuk sarana akomodasi, desa wisata dapat menyediakan sarana penginapan berupa pondok-pondok wisata (Home Stay)sehingga para pengunjung dapat merasakan suasana pedesaan yang masih asli.

Menurut Cooper pada Febrina (2015), daya tarik wisata harus mempunyai empat komponen yaitu: Attraction (atraksi), accessibilities (aksesibilitas), amenities (fasilitas), dan ancillary (jasa pendukung pariwisata). Adapun komponen-komponen tersebut yaitu:

a. Attraction atau atraksi wisata: atraksi wisata yang terdapat di daerah tujuan wisata. Seperti atraksi budaya, alam, dan buatan.

b. Amenities atau fasilitas: sarana dan prasarana yang berhubungan dengan akomodasi.

c. Accessibilities atau aksesibilitas: Segala macam transportasi umum ataupun jasa transportasi menjadi akses penting dalam pariwisata, berhubungan dengan jarak dan kemudahan untuk mencapai tujuan.

d. Ancillary atau jasa pendukung pariwisata: Pelayanan yang disediakan termasuk pemasaran, pembangunan fisik (jalan raya, rel kereta, air minum, listrik, telepon, dan lain-lain) serta mengkoordinir segala macam aktivitas dan segala peraturan perundang-undangan baik di jalan raya maupun di objek wisata

Menurut (Tamin; 2009), aksesibilitas adalah suatu ukuran kenyamanan atau kemudahan lokasi tata guna lahan dalam berinteraksi satu sama lain, dan mudah atau sulitnya lokasi tersebut dicapai melalui transportasi. Pendapat lain tentang aksesibilitas merupakan salah satu bagian dari analisis interaksi kegiatan dengan sistem jaringan transportasi yang bertujuan untuk memahami cara kerja sistem tersebut dan menggunakan hubungan analisis antara komponen sistem untuk meramalkan dampak lalu lintas beberapa tata guna lahan atau kebijakan transportasi yang berbeda.

Menurut (Miro;2004), Tingkat aksesibilitas wilayah bisa ditentukan berdasarkan pada beberapa variabel yaitu ketersediaan jaringan jalan, jumlah alat transportasi, panjang lebar jalan, dan kualitas jalan. Selain itu yang menentukan tinggi rendahnya tingkat akses adalah pola pengaturan tata guna lahan. Keberagaman pola pengaturan fasilitas umum antara satu wilayah dengan wilayah lainnya.

Persyaratan aksesibilitas terdiri dari akses informasi dimana fasilitas harus mudah ditemukan dan mudah dicapai, harus memiliki akses kondisi jalan yang dapat dilalui dan sampai ke tempat obyek wisata, serta harus ada tempat akhir suatu perjalanan. Syarat-syarat tersebut dapat diuraikan sebagai berikut:

a. Akses informasi: Masukan informasi yang lengkap tentunya akan menyebabkan para wisatawan semakin mudah untuk menyeleksi kawasan- kawasan yang akan dikunjungi. Informasi itu dapat berupa promosi dan publikasi.

b. Akses jalan: Akses kondisi jalan menuju obyek wisata, dan jalan akses itu harus berhubungan dengan prasarana umum. Kondisi jalan umum dan jalan akses menentukan aksesibilitas suatu obyek wisata.

c. Tempat akhir suatu perjalanan: Sebagai tempat akhir perjalanan, di tempat objek wisata harus ada 
terminal, setidak-tidaknya tempat parkir. Baik jalan akses maupun tempat parkir harus sesuai dengan kebutuhan yaitu sesuai dengan jumlah wisatawan yang diharapkan kedatangannya dan jenis serta jumlah kendaraan yang diperkirakan akan digunakan oleh para wisatawan.

Transportasi dapat diartikan sebagai kegiatan mengangkut dan memindahkan muatan (barang dan orang/manusia) dari suatu tempat ke tempat lainnya. Perjalanan mengangkut muatan dari tempat asal (origin) ke tempat tujuan (destination) disebut Origin Destination Travel. Orang yang melakukan suatu perjalanan ke suatu tempat atau destinasi wisata dengan menggunakan transportasi akan menghasilkan suatu guna (utility), selain menciptakan guna, transportasi menciptakan pula guna waktu (time utility) karena mampu menghemat waktu perjalanan dalam memberikan pelayanan jasa transportasi. Untuk menyelenggarakan kegiatan transportasi di perlukan tersedianya moda transportasi (sepeda motor, mobil, bus, kapal laut dan pesawat udara) dan muatan (barang atau manusia) yang diangkut, melalui jalan yang tersedia, atau trayek dan rute yang telah ditetapkan.

Menurut Utomo (2015), jenis-jenis transportasi dibagi menjadi tiga, yaitu sebagai berikut :

a. Transportasi darat adalah segala bentuk transportasi menggunakan jalan untuk mengangkut penumpang atau barang. Contoh moda transportasi darat adalah kendaraan bermotor, mobil, bus, dan kereta api.

b. Transportasi air merupakan alat transportasi yang menggunakan media sungai, danau dan laut sebagai landasan operasionalnya. Alat transportasi air contohnya seperti kapal, tongkang, perahu dan rakit.

c. Transportasi udara merupakan alat angkutan mutakhir dan tercepat. Transportasi ini menggunakan pesawat udara sebagai alat angkutan sedangkan udara atau angkasa sebagai jalur atau jalannya.

Dalam Kamus Besar Bahasa Indonesia (2008: 667) mendefinisikan pengertian kendala adalah halangan rintangan dengan keadaan yang membatasi, menghalangi, atau mencegah pencapaian sasaran khususnya dalam bentuk geometri lingkungan. Selain itu adapun kendala-kendala yang dihadapi dalam pariwisata, antara lain : (La Taya, 2012)

a. Kurangnya keamanan pada daerah tujuan wisata

b. Rendahnya mutu pelayanan dari para penyelenggara pariwisata

c. Keterbatasan akses

d. Kelemahan dalam pengemasan produk paket wisata

e. Rendahnya kualitas sumber daya manusia

f. Kurangnya promosi pariwisata yang dilakukan oleh para penyelengara pariwisata

\section{METODE PENELITIAN}

Metode Deskriptif yang digunakan dalam penelitian ini Penelitian ini bertujuan untuk mendeskripsikan identifikasi accessibility pada objek wisata di Desa Sambangan sebagai Desa Wisata dengan memfokuskan pada aksesibiltas (accessibility) objek wisata di Desa Wisata Sambangan serta kendala dalam penyediaan accessibility pada objek wisata di Desa Sambangan. Namun sebelum peneliti terjun ke lapangan ada beberapa hal yang peneliti persiapkan yaitu menentukan topik umum, merumuskan pertanyaan umum untuk memperoleh informasi yang diperlukan, dan metodemetode pengumpulan data.

Penelitian ini dilakukan di Desa Sambangan, Kec. Sukasada, Kab. Buleleng, Provinsi. Dalam penelitian ini 
penulis menggunakan penelitian metode kualitatif dan dianalisis lebih lanjut dalam analisis data. Penelitian ini merupakan cara ilmiah yang digunakan untuk mendapatkan data yang valid. Data adalah suatu fakta atau keterangan dari objek yang diteliti. Jenis data yang ada yang digunakan dalam penelitian ini adalah data kualitatif. Data kualitatif merupakan data yang dinyatakan dalam bentuk kata, kalimat, dan gambar.

Sumber data adalah hal yang sangat penting dalam suatu penelitian serta tempat data diperoleh dengan menggunakan metode tertentu baik berupa manusia, artefak, ataupun dokumendokumen. Pada penelitian ini yang menjadi sumber datanya yaitu: (a) Data yang diperoleh dari hasil wawancara, observasi dan studi dokumentasi dengan sumber data yang diperoleh dari Kepala Desa Sambangan, POKDARWIS Tunjung Mekar, dan Pelaku Wisata. (b) Data yang diperoleh mengenai sejarah dan profil desa, kondisi geografis, demografi desa, keadaan sosial ekonomi, serta jumlah kunjungan wisatawan pada objek wisata, dengan sumber datanya diperoleh dari POKDARWIS Tunjung Mekar, BUMDES GIRI AMERTHA Desa Sambangan dan Pelaku Wisata.

Metode pengumpulan data yang digunakan dalam penelitian ini adalah: metode observasi, metode wawancara, metode dokumentasi. Analisis data dalam penelitian ini yaitu: (1) pengumpulan data, (2) reduksi data, (3) penyajian data dan (4) penarikan kesimpulan.

\section{HASIL DAN PEMBAHASAN}

Desa Sambangan memiliki potensi wisata yang cukup besar. Beberapa objek wisata di Desa Sambangan terdiri dari objek wisata alam, dan objek wisata buatan. Objek wisata alam yang ada di Desa Sambangan terdiri dari, Air Terjun Aling-Aling, Air Terjun Kroya, Air Terjun Pucuk, Air Terjun Kembar, Air Terjun Tembok Barak, Air Terjun Canging, Air Terjun Dedari, dan Air Terjun Cemara.

Accessibility pada objek wisata alam di Desa Sambangan dapat diuraikan sebagai berikut: (a) Akses Informasi: Masukan informasi yang lengkap tentunya akan menyebabkan para wisatawan semakin mudah untuk menyeleksi kawasan- kawasan yang akan dikunjungi. Informasi itu dapat berupa promosi dan publikasi. Pihak pengelola objek wisata alam yang berada dibawah naungan POKDARWIS Tunjung Mekar Desa Sambangan telah mengupayakan promosi dan publikasi melalui membagikan selebaran, pamflet, pemasangan baliho, serta publikasi lewat media sosial seperti facebook, instagram, dan website. (b) Akses Jalan: Sebelum memasuki area objek wisata alam, wisatawan yang datang berkunjung dapat mengaksesnya dengan mudah menggunakan kendaraan roda dua maupun kendaraan roda empat karena kondisi jalan menuju Desa Sambangan terbilang cukup baik dilihat dari kondisi jalan yang sudah beraspal namun ukuran lebar jalan masih terbilang sempit. Selain itu kondisi trotoar untuk pejalan kaki di sepanjang jalan di Desa Sambangan juga terbilang cukup baik. Secara keseluruhan letak objek wisata alam Desa Sambangan berada di tengah hutan, sehingga untuk mengaksesnya wisatawan akan diajak untuk menyusuri jalan setapak semi permanen, dikatakan semi permanen karena terdapat jalan tanah yang menyesuaikan pada alam hutan dan jalan semen di beberapa titik. Pihak pengelola juga telah memasang petunjuk arah agar memudahkan mencapai setiap objek wisata alam serta tersedia gazebo (rest area). (c) Tempat akhir suatu perjalanan: sebagai tempat akhir suatu perjalanan pada objek wisata harus terdapat tempat parkir. Tempat parkir harus sesuai dengan kebutuhan yaitu sesuai dengan jumlah wisatawan yang diharapkan kedatangannya. Area parkir yang disediakan pada objek wisata alam di Desa Sambangan sudah cukup memadai, namun jika jumlah wisatawan yang datang banyak dan melebihi kapasitas area parkir yang ada dirasa belum cukup dan perlu adanya perluasan area parkir

Sedangkan objek wisata buatan yang ada di Desa Sambangan terdiri dari, Krisna Adventure, Palowan Hidroponik 
Sambangan, Alam Sambangan, Kolam Renang Amour Legawa, dan Lanting Paras Restaurant and Pool. Accessibility pada objek wisata buatan di Desa Sambangan dapat diuraikan sebagai berikut: (a) Akses Informasi: untuk lebih dikenal oleh kalangan luas pihak pengelola telah mengupayakan melakukan berbagai jenis promosi dan publikasi dengan cara pemasangan baliho, serta melalui media sosial seperti, facebook, instagram, dan website. Promosi lebih banyak dilakukan melalui media sosial karena dirasa paling efektif sebagai sarana penyebar informasi pada masa ini. (b) Akses Jalan: akses jalan menuju objek wisata buatan yang ada di desa sambangan terbilang cukup mudah, karena secara keseluruhan objek wisatanya terletak di pinggir jalan, hanya saja pada objek wisata Lanting Paras Restaurant and Pool saja yang letaknya masuk ke area pemukiman warga. Wisatawan yang datang berkunjung dapat mengaksesnya dengan mudah menggunakan kendaraan roda dua maupun kendaraan roda empat dengan kondisi jalan beraspal, namun ukuran lebar jalan terbilang sempit. Tidak dapat dipungkiri pada masa high season dengan kondisi jalan yang tergolong sempit sedikit mengganggu laju transportasi sehingga mengakibatkan kemacetan. Pihak pengelola atau owner telah berupaya dalam memberikan keamanan, kenyamanan dan kemudahan pada wisatawan yang berkunjung, dapat dilihat dari dengan pemasangan CCTV untuk merekam segala aktifitas pengunjung, selalu menjaga kebersihan di area objek wisata, serta memasang petunjuk arah agar mudah dicapai oleh wisatawan. (c) Tempat akhir suatu perjalanan: Para pengelola wisata atau owner dari objek wisata buatan di Desa Sambangan telah berupaya untuk menyediakan tempat parkir yang layak bagi para pengunjungnya. Berbeda halnya dengan objek wisata alam, tempat parkir untuk objek wisata buatan letaknya berdampingan dengan objek wisatanya langsung.

Adapun kendala-kendala dalam penyediaan accessibility pada objek wisata
Desa Wisata Sambangan, antara lain: (a) Letak Geografis: Desa Sambangan terletak diatas bukit yang dekat dengan pegunungan, dikatakan sebagai salah satu kendala dalam penyediaan accessibility pada objek wisata di Desa Sambangan karena curah hujannya yang tinggi, sehingga mengakibatkan medan jalan yang dilalui untuk menuju objek wisata khususnya objek wisata alam menjadi sulit. Akan tetapi, letak geografis ini tidak sepenuhnya menjadi kendala dalam penyediaan akses jalan pada objek wisata, dapat dilihat dari saat musim kemarau menjadikan suasana yang sejuk dan tidak terlalu panas karena dekat dengan pegunangan sehingga banyak wisatawan yang ingin berkunjung. (b) Pemodalan: Mengenai pemodalan akan berhubungan langsung dengan dana. Dalam penyediaan akses yang layak pendanaan yang didapatkan dari pemerintah tidak dapat terealisasikan untuk seluruh objek wisata yang ada, sehingga dalam hal ini dana yang ada harus benar-benar dipilah yang akan digunakan untuk memperbaiki dan memperbaharui akses jalan yang rusak. Selain didapat dari pemerintah, sumber dana juga didapatkan dari hasil penjualan tiket namun dana yang didapat masih sangat minim. Dalam menyediakan area parkir juga terkendala di dalam pendanaan, karena tidak dapat dipungkiri pada masa high season memerlukan area parkir yang lebih luas, sehingga harus lebih diperhatikan lagi oleh pihak pengelola. (c) Jalan yang dilalui untuk menuju objek wisata terbilang sempit: Penyediaan jalan yang lebih lebar merupakan sebuah ukuran kenyamanan dan kemudahan untuk mencapai sebuah destinasi wisata. Jalan yang sempit menjadi kendala dalam penyediaan accessibility pada objek wisata Desa Wisata Sambangan karena pada masa high season dan banyak bus-bus dan mobil yang melintas dengan kondisi jalan yang sempit mengakibatkan kemacetan yang parah karena jalan di pedesaan tergolong kecil dibandingkan dengan jalan di kota. Aksesibilitas tidak luput kaitanya dengan jarak dan waktu, jika pada suatu destinasi wisata akses jalan yang disediakan tidak sesuai dengan 
kapasitas wisatawan yang datang maka hal ini merupakan salah satu kendala yang memerlukan perlakuan lebih serius. (d) Kurangnya penerangan jalan pada malam hari: Kurangnya penerangan jalan khususnya di sekitar objek wisata buatan yang buka sampai malam hari mengakibatkan mengganggu keamanan, kenyamanan, serta kemudahan untuk mencapai suatu objek wisata. (d) Pelepasan lahan: terkendala dalam pelepasan lahan karena area parkir yang disediakan di setiap objek wisata terbilang kurang memadai jika jumlah tamu yang berkunjung meningkat. terlebih lagi sebagian lahan yang ada di Desa Sambangan ini bukan sepenuhnya milik masyarakat setempat, melainkan sebagian lahannya milik warga dari desa lain.

\section{SARAN}

Adapun saran dari penelitian ini adalah:

a. Akses jalan termasuk dalam kategori cukup bagus, namun masih perlu dilakukan peningkatan dalam penyediaan akses jalan menuju ke setiap objek wisata yang ada.

b. Di beberapa objek wisata yang baru dibuka sebaiknya dibuatkan treck khusus untuk masuk ke objek wisata tersebut, agar tidak mengganggu wisatawan yang berkunjung maupun warga sekitar Desa Sambangan.

\section{DAFTAR RUJUKAN}

Blog Teknik Planologi. 2015. Desa Wisata Dalam Konteks Industri Pariwisata. Dalam http://www.radarplanologi.com/2015/ 10/desa-wisata-dalam-konteksindustri-pariwisata.html.

Dewi Martha Erli H, Ketut. 2015. Penentuan Prioritas Pengembangan Infrastruktur Kawasan Wisata Bahari di Desa Sumberejo, Desa Lojejer dan Desa Puger Kulon, Kabupaten Jember berdasarkan Preferensi Pengunjung dan Masyarakat. Jurusan Perencanaan Wilayah dan Kota, Fakultas Teknik dan Sipil
Perencanaan, Institut Teknologi Sepulus Nopember (ITS). Jurnal TEKNIK ITS Volume 4, Nomor 1, Tahun 2015.

Irnawati, Ade. 13 April 2016. Industri Pariwisata. Dalam http://industri123.blogspot.com/2016/ 04/industri-pariwisata.html.

Maryaningsih, Novi. Pengaruh Infrastruktur terhadap Pertumbuhan Ekonomi Indonesia. Buletin Ekonomi Moneter dan Perbankan, Volume 17, Nomor 1, Tahun 2014.

Patisa, Roni Dian. 2018. Definisi Pengembangan Pariwisata Bagian 1. Dalam

https://formasiberita.blogspot.com/20 18/01/definisi-

pengembanganpariwisatabagian.html.

Redaksi Haloedukasi. 2013. Pengertian Aksesibilitas Menurut Para Ahli. Dalam

https://haloedukasi.com/aksesibilitas

Suwantoro. 2000. Syarat-syarat aksesibilitas dan pengukuran aksesibilitas yang ideal. Dalam https://textid.123dok.com/document/ nzw9g9gye-konsep-aksesibilitasaksesibilitas-1-pengertian aksesibilitas.html.

Taurus Cahayadi, I Gusti Nyoman. 2015. Kajian Potensi Ekowisata Di Desa Sudaji Sebagai Desa Wisata. Jurusan Teknologi Industri, Fakultas Teknik dan Kejuruan, Universitas Pendidikan Ganesha. Jurnal Bosaparis Pendidikan Kesejahteraan Keluarga Volume 3, Nomor 1, Tahun 2015.

Taya, LA. 2012. Potensi dan Kendala Pengembangan Pariwisata. Dalam http://komunikasipembangunan.blog spot.com/2012/06/potensi-dankendala-pengembangan.html. 
Tourism Soldier. 3 Juni 2013. Teori $4 A$ (Attraction, Amenity, Accessibility, Ancilliary).

Dalam http://www.jejakwisata.com/studies/k ajian-pariwisata/43-4a-yang-wajibuntuk-destinasi-wisata. 